\title{
STUDI KOMPARATIF POTENSI EKONOMI DAN TINGKAT KEMANDIRIAN DAERAH KABUPATEN TABANAN DENGAN KABUPATEN KARANGASEM
}

\author{
Putu Lia Arlika Putri ${ }^{1}$ \\ Ni Putu Santi Suryantini
}

\author{
${ }^{1,2}$ Fakultas Ekonomi dan Bisnis Universitas Udayana (Unud), Bali, Indonesia \\ e-mail: arlika_putri@yahoo.co.id
}

\begin{abstract}
ABSTRAK
Berdasarkan hasil penelitian potensi ekonomi daerah pada Kabupaten Tabanan dan Kabupaten Karangasem, sektor yang sama di kategori sektor unggulan adalah sektor penyediaan akomodasi dan makanan minuman. Pada sektor berkembang adalah sektor industri pengolahan, real estate, jasa perusahaan, jasa pendidikan, jasa kesehatan dan kegiatan sosial, dan jasa lainnya. Pada sektor potensial adalah sektor pertanian, kehutanan, dan perikanan, dan konstruksi. Berdasarkan hasil uji T diketahui bahwa nilai probabilitas sebesar 0,016 > 0,05, maka dapat disimpulkan bahwa terdapat perbedaan yang signifikan antara tingkat kemandirian daerah Kabupaten Tabanan dengan Kabupaten Karangasem, yang berarti Kabupaten Tabanan memiliki nilai rata-rata lebih tinggi dibandingkan dengan Kabupaten Karangasem. Upaya pemerintah daerah untuk mengoptimalkan potensi ekonomi daerah dengan memprioritaskan sektor yang tergolong unggulan dan potensial, namun tidak mengabaikan sektor-sektor lainnya. Untuk meningkatkan tingkat kemandirian daerah melalui upaya yang besar dalam menggali sumber PAD potensial melalui penerimaan yang bersumber dari peningkatan pajak, retribusi, pengelolaan BUMD dan rencana pengembangan kawasan strategis.
\end{abstract}

Kata Kunci: otonomi daerah, potensi ekonomi daerah, tingkat kemandirian daerah

\begin{abstract}
Based on the result of research of regional economic potency in Tabanan and Karangasem regency, the same sector in the sector of superior category is the sector of accommodation and food drink provision. In developing sectors are manufacturing industry sector, real estate, corporate services, education services, health services and social activities, and other services. Potential sectors are agriculture, forestry, fisheries and construction. Based on result of $T$ test known that probability value equal to 0,016>0,05, hence can be concluded that there is significant difference between level of independence area of Tabanan regency with Regency of Karangasem, which mean Tabanan regency has higher mean value compared to Regency of Karangasem. Efforts by local governments to optimize the economic potential of the region by prioritizing sectors that are classified as potential and potential, but not ignore other sectors. To increase the level of regional autonomy through great efforts in exploring potential sources of $P A D$ through revenues sourced from increased taxes, levies, management of local enterprises and strategic area development plans.
\end{abstract}

Keywords: regional autonomy, regional economic potential, regional level of independence 


\section{PENDAHULUAN}

Era globalisasi menghadapkan Indonesia pada suatu tuntutan untuk melaksanakan pembangunan di segala bidang secara merata, termasuk juga menuntut kesiapan setiap daerah untuk mampu ikut serta mengawasi didalamnya. Dasar dari otonomi daerah memakai teori otonomi sebesar-besarnya berarti daerah diserahkan hak penuh untuk mengatur dan membentuk seluruh kepentingan yang berkaitan dengan pemerintahan selain yang termasuk dalam kepentingan Pemerintah Pusat yang tercantum pada UU No 32 Tahun 2004. Potensi ekonomi daerah merupakan potensi perekonomian yang terdapat pada tempat yang ada dan memiliki kelayakan untuk dibangun dan dapat selalu bertumbuh sehingga berguna bagi masyarakyat di daerah tersebut sebagai sumber pendapatan juga bisa menjadi pendorong ekonomi di daerah tersebut secara universal, daerah tersebut dapat berkembang dengan sendirinya dan berkelanjutan (Suparmoko, 2002:99). Rasio kemndirian keuangn darah (Rasio KKD) merupakan kebisaan pemda untuk melakukan pembiayaan pribadi pada setiap aktivitas pemerintah, pengembangan daerah, serta pemberian layanan pada masyarakat yang sudah melakukan pembayaran pajak juga retribusi bagi sumber pendanaan yang dibutuhkan (Halim, 2002:128).

Penelitian ini di lakukan pada Kabupaten di Bali timur yaitu Kabupaten Karangasem dan Bali barat yaitu Kabupaten Tabanan. Kabupaten Karangasem di pilih dalam penelitian ini karena memiliki potensi yang unik dan langka di bandingkan dengan Kabupaten lain, yaitu potensi dalam bidang Galian C. Selain itu Kabupaten Karangasem juga memiliki keunikan pada objek wisata yang 
terdapat pada Kabupaten ini, yaitu wisata spiritual seperti Pura Besakih. Sedangkan Kabupaten Tabanan dipilih karena memiliki keunikan dalam potensi yang dimilikinya yaitu dalam bidang pertanian Beras Merah yang sudah di ekspor ke Filipina dan Jepang, selain itu Kabupaten Tabanan merupakan satu-satunya penghasil beras merah di Bali yang sudah di ekspor ke luar negeri. Objek wisata yang dimiliki oleh Kabupaten ini lebih banyak pada ekowisata, seperti ekowisata di subak Jatiluwih. Karena keunikan yang dimiliki oleh kedua Kabupaten tersebut, maka penelitian ini di lakukan pada Kabupaten Karangasem dan Kabupaten Tabanan. Laju pertumbuhan ekonomi di Kabupaten Tabanan pada tahun 2016 mengalami penurunan dari 6,25 persen pada tahun 2015, menjadi 6,12 persen.

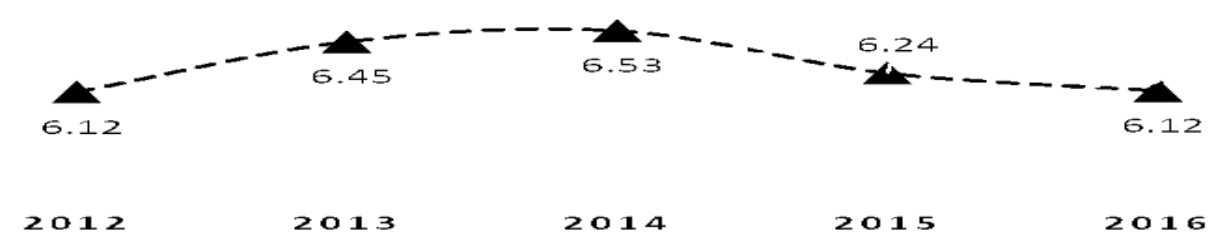

Gambar 1. Perkembangan Laju Pertumbuhan Ekonomi Kabupaten Tabanan (Persen) Tahun 2012-2016

Sumber: BPS Kabupaten Tabanan, 2017

Gambar 1 menunjukkan bahwa laju pertumbuhan ekonomi di Kabupaten Tabanan pada tahun 2016 mengalami penurunan dari 6,25 persen pada tahun 2015, menjadi 6,12 persen. Selama tahun 2012-2016 laju pertumbuhan ekonomi Tabanan memiliki kecendrungan meningkat. Di tahun 2012, laju pertumbuhan ekonomi Tabanan adalah sebesar 6,12 persen, kemudian meningkat di tahun 2013 menjadi 6,45 persen, tahun 2014 menjadi 6,53 persen, tahun 2015 menjadi 6,25 persen, dan tahun 2016 mengalami penurunan menjadi 6,12 persen. Wilayah 
administrasi Kabupaten Tabanan terdiri dari sepuluh kecamatan yaitu Kecamatan Silemadeg, Krambitan, Tabanan, Kediri, Marga, Baturiti, Penebel, Pupuan Selemadeg Barat dan Selemadeg Timur, sehingga luas wilayah Kabupaten Tabanan secara keseluruhan seluas $839,33 \mathrm{Km}^{2}$ atau sebesar 14,90 persen dari luas Pulau Bali $\left(5.632,786 \mathrm{Km}^{2}\right)$

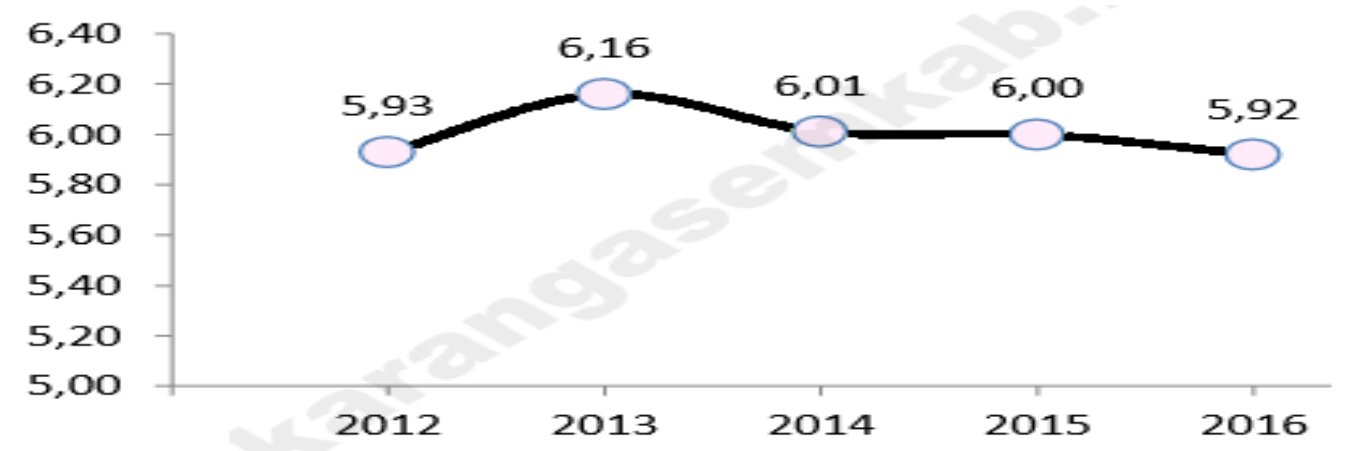

Gambar 2. Perkembangan Laju Pertumbuhan Ekonomi Kabupaten Karangasem (Persen) Tahun 2012-2016

Sumber: BPS Kabupaten Karangasem, 2017

Pada tahun 2012 laju pertumbuhan ekonomi Kabupaten Karangasem tumbuh sebesar 5,93 persen, tahun 2013 tumbuh meningkat sebesar 6,16 persen, pada tahun 2014 mengalami penurunan sebesar 6,01 persen, tahun 2015 menurun menjadi 6,00 persen, dan pada tahun 2016 ekonomi Kabupaten Karangasem Tumbuh sebesar 5,92 persen, angka ini lebih rendah dibandingkan tahun sebelumnya yang mencapain 6,00 persen (BPS Kabupaten Karangasem:101). Karangasem adalah Kabupaten berlokasi pada sisi sebelah timur Provinsi Bali. Secara geografis, daerah ini terletak di posisi $8^{0} 00^{\prime} 00^{\prime \prime}-8^{0} 41^{\prime} 37,8^{\prime \prime}$ Lintang Selatan dan $115^{0} 35^{\prime} 9,8^{\prime \prime}-115^{0} 54^{\prime} 8,9^{\prime \prime}$ Bujur Timur yang menyebabkan karangasem memiliki iklim tropis seperti halnya daerah lain pada Pulau Bali. Kabupaten Karangasem, memiliki luas wilayah mencapai $839,54 \mathrm{~km}^{2}$. Dengan 
luas sebesar itu, Kabupaten Karangasem menjadi Kabupaten dengan wilayah terbesar nomer tiga pada Pulau Bali, dibawah Buleleng serta Jembrana.

Menurut Arsyad (2015:389) yang digunakan untuk pengukuran pertumbuhan ekonomi yang berhubungan dengan potensi ekonomi daerah yaitu Shift Share, Location Quotient (LQ), Model Rasio Pertumbuhan (MRP), Overlay, dan Tipologi Klassen. Analisis Shift Share menunjukkan hasil serta productivity sector pada keadaan ekonomi sebuah daerah caranya adalah menghitung laju pertumbuhan sektor perekonomian daerah (Kabupaten atau Kota) dibandingkan laju pertumbuhan keadaan ekonomi di tingkat yang lebih tinggi (Provinsi). $L Q$ merupakan suatu pendekatan untuk mengukur kinerja basis ekonomi suatu daerah atau proses uji beberapa sektor perekonomian yang masuk pada kategori di sektor unggulan.

Menurut Sjafrizal (1997) dalam Dominica (2010) Tipologi Kassen adalah teknik analisis gabungan atau perpaduan antara hasil perhitungan $L Q$ dan MRP. Dengan menggunakan analisis Tipologi Klassen, suatu sektor dapat dikelompokan kedalam empat kategori, yaitu sektor unggulan (prima), sektor potensial, sektor berkambang, dan sektor terbelakang (Mahmudi, 2009:52). Alat analisis yang digunakan dalam penelitian ini adalah analisis Tipologi Klassen untuk mengidentifikasi potensi ekonomi daerah sektor unggulan sampai sektor terbelakang pada daerah Kabupaten Tabanan dan Kabupaten Karangasem. Analisis Tipologi Klassen digunakan karena lebih efisien dalam perhitungan, selain itu analisis Tipologi Klassen telah mengadopsi dua hasil perhitungan yaitu $L Q$ dan MRP. Sedangkan untuk mengukur tingkat kemandirian daerah penelitian 
ini menggunakan rasio kemandirian untuk mengidentifikasi tingkat kemandirian daerah dan menggunakan iji $\mathrm{T}$ untuk menguji perbedaan tingkat kemandirian daerah Kabupaten Tabanan dan Kabupaten Karangasem.

Ascani dkk. (2012) menganalisis pembangunan ekonomi regional. Hasilnya meningkatnya permintaan untuk desentralisasi kekuasaan, sumber daya dari pemerintah pusat ke pemerintah daerah, dan lokal di sebagian besar dunia dalam dekade terakhir dapat diartikan sebagai pengakuan bahwa pasukan regional dan karakteristik yang sangat relevan dalam membentuk pembangunan daerah dalam konteks meningkatnya globalisasi. Kerimoglu dan Karahasan (2012) meneliti kesenjangan antar daerah di Spanyol. Hasilnya kinerja ekonomi menunjukkan dampak positif yang signifikan dari bakat aktivitas ekonomi regional. Konsentrasi kerja di sektor-sektor tertentu memainkan peran penting dalam akuntansi untuk perbedaan regional, sementara dampak dari kerja berpendidikan tinggi juga penting untuk kegiatan ekonomi, tidak hanya dampak spesifik akumulasi modal manusia pada perbedaan regional tetapi juga peran inovatif dan kreatif kerja dapat dipahami dengan memeriksa dispersi ini.

Fattah dan Rahman (2013) meneliti pembangunan ekonomi daerah di Kabupaten atau Kota di Provinsi Sulawesi Selatan di Indonesia, menggunakan analisis Tipologi Klassen. Hasilnya dari dua pulih tiga Kabupaten atau Kota di Provinsi Sulawesi Selatan, hanya Luwu Timur, Makassar, dan Pare-Pare yang termasuk dalam klasifikasi pertumbuhan yang tinggi dan berpenghasilan tinggi daerah. Huggins (2013) menganalisis daya saing daerah. Hasilnya model daya saing daerah biasanya secara implisit dibangun dalam silsilah kerangka 
pertumbuhan endogen, dimana investasi yang disengaja dalam faktor-faktor seperti modal manusia dan pengetahuan dianggap pendorong utama perbedaan pertumbuhan.

Afandiyev, dkk. (2014) meneliti di wilayah Greater Baku ibu kota Republik Azerbaijan.Berdasarkan hasil analisis faktor-faktor positif dan negatif yang mempengaruhi pengembangan lebih lanjut Greater Baku didefinisikan bersamasama dengan menunjukkan cara-cara pembangunan yang optimal. Dalam rangka untuk mencegah perluasan wilayah Greater Baku dan overloading kota, penjelasan ilmiah dan masyarakat serta peraturan ekonomi, administrasi dan kependudukan harus dilakukan, subordinasi administrasi Greater Baku ke pusat dalam hal memecahkan masalah yang ada. Boronenko dan Zeibote (2011) meneliti potensi pengembangan cluster dan peran kebijakan cluster dukungan di Latvia, menggunakan analisis komparatif konsentrasi regional angkatan kerja oleh sektor-sektor ekonomi di Latvia dan Finlandia. Hasilnya Finlandia memiliki konsentrasi tenaga kerja daerah jauh lebih kuat di sektor-sektor tertentu dari ekonomi, yang tidak khas untuk Latvia dan mengungkapkan bahwa perekonomian daerah dari Latvia memiliki potensi jauh lebih rendah untuk pengembangan claster dan daya saing di pasar global.

Dari penelitian yang sudah dilakukan pada berbagai daerah terlihat sangat pentingnya potensi ekonomi dan tingkat kemandirian daerah untuk dianalisis dalam rangka peningkatkan penghasilan dan kemandirian daerah agar dapat menyelenggarakan pertumbuhan ekonomi. Berdasarkan fenomena yang dialami Kabupaten Tabanan dan Kabupaten Karangasem yang telah dijabarkan, maka 
dapat dibuat rumusan masalah dari penelitian ini (1) Bagaimana potensi ekonomi daerah Kabupaten Tabanan?, (2) Bagaimana potensi ekonomi daerah Kabupaten Karangasem?, (3) Bagaimanakah perbandingan potensi ekonomi daerah Kabupaten Tabanan dengan Kabupaten Karangasem?, (4) Bagaimana tingkat kemandirian daerah Kabupaten Tabanan?, (5) Bagaimana tingkat kemandirian daerah Kabupaten Karangasem?, (6) Bagaimanakah perbandingan tingkat kemandirian daerah Kabupaten Tabanan dengan Kabupaten Karangasem?. Tujuan penelitian ini adalah (1) Untuk mengkaji potensi ekonomi daerah Kabupaten Tabanan. (2) Untuk mengkaji potensi ekonomi daerah Kabupaten Karangasem. (3) Untuk mengkaji perbandingan potensi ekonomi daerah Kabupaten Tabanan dengan Kabupaten Karangasem. (4) Untuk mengkaji tingkat kemandirian daerah Kabupaten Tabanan. (5) Untuk mengkaji tingkat kemandirian daerah Kabupaten Karangasem. (6) Untuk mengkaji perbandingan tingkat kemandirian daerah Kabupaten Tabanan dengan Kabupaten Karangasem. Kegunaan teoritis dari penelitian ini diharapkan dapat menjadi sumber informasi bagi para peneliti berikutnya yang meneliti topik yang sejenis di bidang potensi ekonomi daerah dan tingkat kemandirian daerah. Kegunaan praktis penelitian ini diharapkan dapat digunakan sebagai masukan dalam melakukan analisis perbandingan potensi ekonomi dan tingkat kemandirian daerah, yang pada akhirnya dapat memberikan sumber informasi bagi pemerintah daerah.

Landasan teori penelitian ini adalah otonomi daerah. Tercantum pada UU Nomor 32 Tahun 2004 mengenai pemerintah daerah, Otonomi Daerah merupakan hak, wewenang, dan kewajiban daerah otonom dalam mengatur dan mengurus 
Putu Lia Arlika Putri, Studi Komparatif Potensi Ekonomi.....

langsung segala aktivitas pemerintahan serta segala kepentingan rakyat didaerahnya berpedoman pada perpu. Daerah otonom merupakan satu-kesatuan rakyat hukum dan memiliki batas daerah yang berwewenang dalam pengaturan serta pengurusan segala kegiatan pemerintah juga seluruh keperluan rakyat daerah berdasar pada pikiran sendiri sesuai aspirasi rakyatnya sesuai sistem NKRI. Penyelenggaraan urusan pemerintah dilakukan oleh Pemerintah Daerah dan Dewan Perwakilan Rakyat Daerah (DPRD) berdasarkan asas otonomi dan tugas pembantuan dengan prinsip otonomi seluas-luasnya. Desentralisasi fiskal memberikan keleluasaan kepada daerah untuk mengelola keuangan daerah sesuai dengan aspirasi, prioritas, dan kebutuhan daerah. Kunci keberhasilan otonomi daerah dan desentralisasi fiskal di masing-masing Pemerintahan Daerah sebenarnya terletak pada kemampuan Pemerintahan Daerah melakukan tata kelola keuangan daerah yaang baik.

Landasan teori kedua penelitian ini adalah PDRB. Menurut BPS (2002:3) PDRB yang lebih diketahui dengan sebutan pendapatan regional adalah data statistika yang telah menjadi rangkuman diperolehnya nilai tambahan pada aktivitas perekonomian di suatu daerah. Melakukan hitungan Produk Domestik Regional Bruto bisa dikerjakan memakai 2 metode seperti metode langsung serta metode tidak langsung.

Landasan teori ketiga penelitian ini adalah Pendapatan Asli Daerah (PAD). Menurut Undang-Undang No. 33 Tahun 2004 tentang Perimbangan antara Pemerintah Pusat dan Pemerintah Daerah, yang dimaksud dengan Pendapatan Asli Daerah (PAD) merupakan pendapatan dipungut berdasar kepada Perda yang 
cocok menurut perpu. Pendapatan Asli Daerah memiliki tujuan memberi kewenangan pada pemda yang digunakan dalam menjadi dana dalam melaksanaan otonomi daerah yang cocok pada potensi di wilayah sebagai wujud dari desentralisasi, sehingga dengan semakin banyaknya penerimaan PAD yang diterima pemerintah daerah, maka pembangunan perekonomian daerah tersebut akan semakin meningkat. Secara sederhana dapat dikatakan bahwa semakin besar PAD maka semakin mandiri daerah dalam mengambil keputusan dan kebijakan pembangunan (Nuryanti 2015:22). Mahmudi (2009:18) kenaikan tingkat mandirinya suatu wilayah sangat berkaitan pada mampu atau tidaknya wilayah tersebut untuk melakukan pengelolaan Pendapatan Asli Daerah. Makin besar tingkat mampunya sebuah wilayah untuk meningkatkan Pendapatan Asli Daerah, jadi diskresi wilayah juga makin tinggi dalam penggunaan Pendapatan Asli Daerah itu cocok dengan pendapat, kebutuhan, dan prioritas pembangunan wilayah. Pendapatan Asli Daerah adalah salah satu sumber pendapatan wilayah memiliki keterkaitan dengan pertumbuhan ekonomi, dimana PAD dapat dikatakan sebagai modal yang digunakan dalam pembiayaan pembangunan daerah.

Landasan teori keempat penelitian ini adalah potensi ekonomi daerah. Soeparmoko (2002) dalam Erawati dan Mahendra (2012) Potensi perekonomian wilayah merupakan mampu atau tidaknya perekonomian di wilayah tersebut memungkinkan serta layak dibangun lagi, jadinya potensi tersebut dapat terus dikembangkan dan jadi sumber pendapatan masyarakat di daerah tersebut, hal ini dapat juga menolong keadaan ekonomi dengan seluruh suatu wilayah agar dapat tumbuh kembang secara pribadinya serta berkelanjutan. Mahmudi (2009:16) 
potensi ekonomi daerah merupakan sumber pendapatan daerah yang pada dasarnya dapat dibedakan menjadi dua yaitu (1) sumber pendapatan yang saat ini ada dan sudah ditetapkan dengan peraturan perundang-undangan, (2) sumber pendapatan dari potensi ekonomi daerah yang berpotensial atau tersembunyi dan baru akan diperoleh hasilnya di masa datang apabila sudah dilakukan upaya-upaya tertentu.

Landasan teori kelima penelitian ini adalah kemandirian daerah. Berdasar pada Halim (2007:232), mandirinya keuangan suatu wilayah akan terlihat dari tinggi rendahnya PAD jika dihitung perbandingannya dengan penerimaan suatu wilayah yang asalnya dari sumber lainnya, seperti dana dari pemerintah pusat atau juga dana hasil pinjam. Mandirinya keuangan suatu wilayah memberikan gambaran tergantungnya suatu wilayah pada sumber dana eksternal. Makin besar tingkat mandirinya memiliki pengertian bahwasannya tingkat tergantungnya suatu wilayah pada bantuan pihak eksternal (seperti dari pemerintah pusat dan provinsi) makin kecil serta begitu juga sebaliknya. Rasio kemandirian juga memberikan gambaran bagaimana partisipasi rakyat daerah tersebut terhadap pembangunan daerah, makin besar rasio kemandirian, makin besar pula partisipasi rakyat daerah untuk membayar pajak juga retribusi wilayah yang adalah komponen Pendapatan Asli Daerah.

Berdasarkan uraian tersebut, dapat di simpulkan bahwa perbedaan tingkat kemandirian daerah Kabupaten Tabanan dengan Kabupaten Karangasem akan berbeda antara Kabupaten Tabanan dan Kabupaten Karangasem, sehingga rumusan hipotesis untuk menguji perbedaan tingkat kemandirian daerah 
Kabupaten Tabanan dengan Kabupaten Karangasem adalah H1: Ada perbedaan tingkat kemandirian antara daerah Kabupaten Tabanan dengan Kabupaten Karangasem.

\section{METODE PENELITIAN}

Penelitian berikut memakai pendekatan kuantitatif dengan berbentuk deskriptif dengan membandingkan serta menghitung rata-rata kontribusi sektoral terhadap rata-rata PDRB Kabupaten Tabanan dengan Kabupaten Karangasem berdasar kepada harga konstan sesuai dengan lapangan usaha tahun 2012-2016 serta laju pertumbuhan PDRB masing-masing sektor dengan laju pertumbuhan PDRB Kabupaten Tabanan dan Kabupaten Karangasem berdasar kepada harga konstan sesuai dengan lapangan usaha tahun 2012-2016. Selanjutnya, mengkasifikasikan hasil perhitungan ke dalam matriks Tipologi Klassen. Terakhir, menginterpretasikan dan menggambarkan hasil perhitungan sektor lapangan usaha yang menjadi potensi ekonomi daerah Kabupaten Tabanan dan Kabupaten Karangasem pada tahun 2012-2016.

Kemudian mengukur tingkat kemandirian Daerah Kabupaten Tabanan dan Kabupaten Karangasem untuk periode waktu tahun 2012-2016, dengan menggunakan pendekatan rasio kemandirian daerah Kabupaten Tabanan dan Kabupaten Karangasem. Untuk menguji perbedaan tingkat kemandirian Kabupaten Tabanan dengan Kabupaten Karangasem penelitian ini menggunakan uji T (Paired Sample T Test) sebagai alat analisis untuk mengetahui tingkat signifikansi perbedaan antara Kabupaten Tabanan dengan Kabupaten Karangasem pada data rata-rata tingkat rasio kemandirian keuangan daerah Pemerintah Daerah 
Kabupaten Tabanan dengan Kabupaten Karangasem Periode 2012-2016. Lokasi dari penelitian ini dilakukan pada Kabupaten Tabanan dan Kabupaten Karangasem dengan menggunakan data PDRB atas dasar harga konstan dan data Pendapatan Asli Daerah (PAD) periode pangamatan lima tahun yaitu 2012-2016 yang diakses melalui situs resmi Badan Pusat Statistik (BPS) yaitu www.bps.co.id. Penelitian ini memilih lokasi pada Kabupaten Tabanan dan Kabupaten Karangasem bertujuan untuk mengetahui tingkat kemandirian daerah dan meningkatkan kinerja pemerintah daerah tingkat II terkait dengan pengoptimalan pengelolaan potensi ekonomi daerah yang dimilikinya.

Obyek yang digunakan dalam penelitian ini untuk menganalisis potensi ekonomi adalah tujuh belas sektor menurut lapangan usaha seperti (1) sektor Pertanian, Kehutanan serta Perikanan; (2) Pertambangan serta Penggalian; (3) Industri Pengolahan; (4) Pengadaan Listrik juga Gas; (5) Pengadaan Air, Pengelolaan Sampah serta Daur Ulang; (6) Construction; (7) Perdagangan Bebas juga Eceran, Reparasi Mobil serta Sepeda Motor; (8) Transportation serta Pergudangan; (9) Penyediaan Akomodasi juga Makan Minum; (10) Information and communication; (11) Jasa Keuangan serta Asuransi; (12) Real Estat; (13) Jasa Perusahaan; (14) Administrasi Pemerintah, Pertahanan juga Jaminan Sosial Wajib; (15) Jasa Pendidikan; (16) Jasa Kesehatan serta Kegiatan Sosial; (17) Jasa Lainnya,, sektor tersebut terdapat dalam data PDRB, sedangkan untuk menganalisis tingkat kemandirian daerah penelitian ini menggunakan data PAD tahun 2012-2016. 
Penelitian ini dilakukan untuk mengetahui potensi ekonomi dan tingkat kemandirian daerah Kabupaten Tabanan dengan Kabupaten Karangasem. Potensi ekonomi daerah Kabupaten Tabanan dan Kabupaten Karangasem merupakan suatu sumber daya yang dimilikinya yang diidentifikasi dalam bentuk sektor lapangan usaha dalam PDRB pada tahun 2012-2016, jika dikelola akan mampu memberikan kontribusi terhadap pendapatan daerahnya. Sedangkan tingkat kemandirian daerah Kabupaten Tabanan dan Kabupaten Karangasem merupakan mampu atau tidaknya wilayah dalam melakukan pengeluaran dana dan bersumber dari wilayah melalui Pendapatan Asli Daerah serta bergantung dengan mampunya wilayah tersebut melakukan realisasi perekonomian yang potensial menuju beberapa bentuk aktivitas perekonomian yang dapat membuat aliran dana dalam proses pembangunan wilayah yang berkesinambungan. Potensi ekonomi daerah diukur berdasarkan pendekatan Tipologi Kassen, sedangkan tingkat kemandirian daerah diukur berdasarkan rasio kemandirian daerah. Maka variabel penelitian yang digunakan adalah potensi ekonomi daerah dan tingkat kemandirian daerah Kabupaten Tabanan dan Kabupaten Karangasem.

Penelitian ini menggunakan data kualitatif dan data kuantitatif. Data yang digunakan berupa data sekunder yang diperoleh dari data yang telah ipublikasikan oleh website BPS. Pengumpulan data dilakukan dengan observasi non partisipan. Teknik analisis data yang digunakan adalah Tipologi Klassen dan Rasio Kemandirian. Berdasar pada penelitian Mahmudi (2009:55) analisa Tipologi Klassen, beberapa tingkat yang harus dilalui antara lain (1) Menilai rata-rata

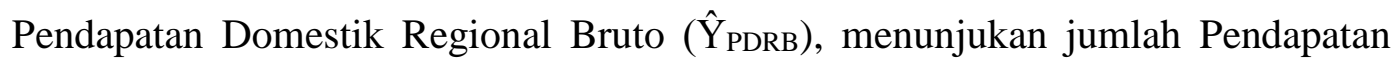


Domestik Regional Bruto selanjutnya dibagi $\mathrm{n}$ tahun $(\mathrm{n}$ tahun $=$ total tahun penelitian). Hitungan rata-rata itu lalu dibagi n sektor lapangan usaha (n sektor lapangan usaha = total sektor lapangan usaha yang dihitung). (2) Menilai rata-rata andil sektoral pada Pendapatan Domestik Regional Bruto ( $\left.\hat{\mathrm{Y}}_{\text {SEKTOR }}\right)$, ini menilai jumlah kontribusi beberapa sektoral, dibagi n tahun.

(3) Menilai rata-rata laju pertumbuhan Pendapatan Domestik Regional Bruto ( tahun. Selanjutnya, menghitung rata-rata pertumbuhan sektoral (rSEKTOR), caranya menghitung jumlah laju pertumbuhan beberapa sektor lalu dibagi $\mathrm{n}$ tahun. (4) Melakukan perbandingan pada hitungan rata-rata andil sektor dengan Pendapatan Domestik Regional Bruto dan rata-rata Pendapatan Domestik Regional Bruto lalu dilakukan perbandingan terhadap jumlah hitungan rata-rata laju pertumbuhan sektoral Pendapatan Domestik Regional Bruto terhadap rata-rata laju pertumbuhan Pendapatan Domestik Regional Bruto. (5) Diklasifikasikan beberapa sektor lapangan usaha pada matriks Tipologi Klassen.

Sektor-sektor dalam Tipologi Klassen terdiri dari empat sektor yaitu (1) Sektor prima (unggul), hasil rata-rata andil sektoral pada Pendapatan Domestik Regional Bruto ( $\hat{\mathrm{Y}}_{\text {SEKTOR}}$ ) lebih tinggi dibandingkan rata-rata Pendapatan Domestik Regional Bruto ( $\hat{\mathrm{Y}}_{\mathrm{PDRB}}$ ) serta hasil rata-rata laju pertumbuhan sektoral (rSEKTOR) lebih tinggi dibandingkan rata-rata laju pertumbuhan Pendapatan Domestik Regional Bruto ( $\left.\mathrm{r}_{\mathrm{PDRB}}\right)$. (2) Sektor potensial, hasil rata-rata andil

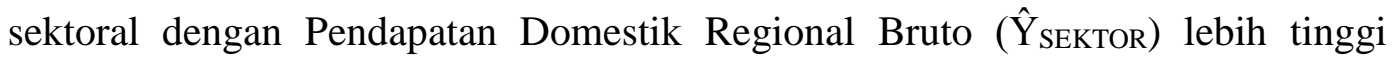

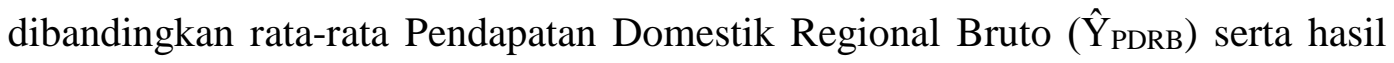


rata-rata laju pertumbuhan sektoral (rSEKTOR) lebih rendah dibandingkan rata-rata laju pertumbuhan Pendapatan Domestik Regional Bruto (rPDRB).

(3) Sektor berkembang, hasil rata-rata andil sektoral dengan Pendapatan

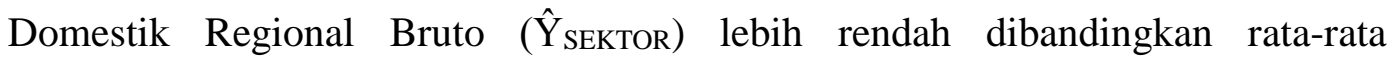

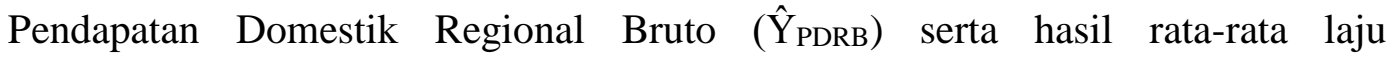
pertumbuhan sektoral ( $\mathrm{r}_{\text {SEKTOR}}$ ) lebih tinggi dibandingkan rata-rata laju pertumbuhan Pendapatan Domestik Regional Bruto (rPDRB). (4) Sektor terbelakang, hasil rata-rata andil sektoral dengan Pendapatan Domestik Regional

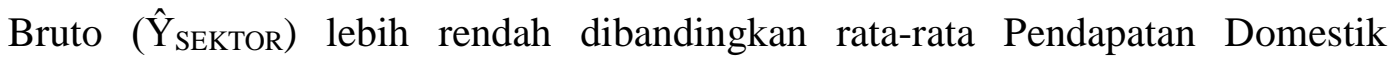
Regional Bruto ( $\hat{\mathrm{Y}}_{\mathrm{PDRB}}$ ) serta hasil rata-rata laju pertumbuhan sektoral ( $\mathrm{r}_{\text {SEKTOR }}$ ) lebih rendah dibandingkan rata-rata laju pertumbuhan Pendapatan Domestik Regional Bruto (rPDRB).

Kriteria Pengukuran:

Tabel 1 Skala Interval Kemandirian Keuangan Daerah

\begin{tabular}{cc}
\hline Persentase & Kemampuan Keuangan Daerah \\
\hline $0,00-10,00 \%$ & Sangat Kurang \\
$10,01-20,00 \%$ & Kurang \\
$20,01-30,00 \%$ & Sedang \\
$30,01-40,00 \%$ & Cukup \\
$40,01-50,00 \%$ & Baik \\
$>50,00 \%$ & Sangat Baik \\
\hline
\end{tabular}

Sumber: Tim Litbang Depdagri Fisipol UGM, 2017

Tingkat mandirinya sebuah wilayah merupakan standar yang memperlihatkan mampu tidaknya pemda untuk melakukan pendanaan mandiri aktivitas pemerintah seperti proses pembangunan wilayah juga proses layanan pada rakyat banyak, yang dinilai melalui ratio Pendapatan Asli Daerah pada total 
penerimaan wilayah tersebut yang masuk juga seperti hibah dari pusat serta pinjaman. Berdasar pada Halim (2007:232) rumus yang digunakan dalam pengukuran tingkat kemandirian daerah yaitu:

Rasio Kemandirian $=\frac{\text { Pendapatan Asli Daerah }}{\text { Transfer Pemerintah Pusat }+ \text { Provinsi dan Pinjaman }} \times 100 \%$

Untuk melakukan uji T (Paired Sample T Test), langkah-langkah yang dilakukan adalah sebagai berikut: 1) Bukalah SPSS worksheet, click Variable View, lalu di sektor Name ketikan Tabanan dan Karangasem. 2) Klik Data View, masuk pada tahap pengisian data, yaitu dengan cara memasukkan angka yang terdapat pada persentase PAD/TPD pada tingkat rasio kemandirian keuangan daerah pemerintah daerah Kabupaten Tabanan dan Kabupaten Karangasem periode 2012-2016. 3) Pada bagian menu yang ada di SPSS click Menu Analyze, selanjutnya klik Compare Means, lalu pilih Paired-Sample T Test. 4) Sehabis beberapa step itu dilakukan kemudian tampak hasil berupa tabel dialog yang bernama Paired-Sample T Test. Disebabkan yang akan di uji adalah data Tabanan serta Karangasem, jadi click di data Tabanan, lalu click tombol yang ada dalam proses memasukan data Karangasem pada kotak Paired Variables. 5) Click Ok, lalu muncul hasil keluaran SPSS (hasil uji Paired Sample T Test).

\section{HASIL DAN PEMBAHASAN}

Perekonomian potensial daerah yang jadi ungulan di Kabupaten Tabanan dalam periode lima tahun belakangan yang hasil $\hat{\mathrm{Y}}_{\text {SEKTOR }} \geq \hat{\mathrm{Y}}_{\mathrm{PDRB}}$ sejumlah $\mathrm{Rp}$. 701.929,63 juta serta $\mathrm{r}_{\mathrm{SEKTOR}} \geq \mathrm{r}_{\mathrm{PDRB}}$ sejumlah 6,34 persen adalah (1) perdagangan besar serta eceran; reparasi mobil juga sepeda motor, (2) penyediaan akomodasi 
dan makan minum, (3) Information and communication, (4) administrasi pemerintahan, pertahanan serta jaminan sosial wajib.

Perekonomian potensial daerah yang berkembang di Kabupaten Tabanan yang hasil $\hat{Y}_{\text {SEKTOR }}<\hat{Y}_{\text {PDRB }}$ sejumlah Rp. 701.929,63 juta serta r $_{\text {SEKTOR }} \geq$ rDDRB $_{\text {P }}$ sejumlah 6,34 persen adalah (1) industri pengolahan, (2) transportasi dan pergudangan, (3) jasa keuangan dan asuransi, (4) real estate, (5) jasa perusahaan, (6) jasa pendidikan, (7) jasa kesehatan dan kegiatan sosial, (8) jasa lainnya.

Perekonomian potensial daerah yang potensial pada Kabupaten Tabanan yang hasil $\hat{Y}_{\text {SEKTOR }} \geq \hat{Y}_{\text {PDRB }}$ sejumlah Rp. 701.929,63 juta serta rSEKTOR $_{\text {PDDRB }}$ sejumlah 6,34 persen adalah (1) Pertanian, Kehutanan, serta Perikanan, juga (2) Konstruksi. Perekonomian potensial yang terbelakang di Kabupaten Tabanan dalam periode lima tahun belakangan yang hasil $\hat{Y}_{\text {SEKTOR }}<\hat{Y}_{\text {PDRB }}$ sejumlah $R p$. 701.929,63 juta serta rSEKTOR $_{\text {< }}$ rDRB sebesar 6,34 persen adalah (1) pertambangan dan penggalian, (2) pengadaan listrik dan gas, (3) pengadaan air, pengelolaan sampah, limbah.

Potensi ekonomi daerah ungulan di Kabupaten Karangasem dalam periode lima tahun belakangan yang hasil $\hat{Y}_{\text {SEKTOR }} \geq \hat{Y}_{\text {PDRB }}$ sejumlah Rp. 500.470,73 juta sektor $\mathrm{r}_{\text {SEKTOR }} \geq \mathrm{r}_{\mathrm{PDRB}}$ sejumlah 6,02 persen adalah (1) transportasi dan ergudangan, (2) penyediaan akomodasi dan makan minum. Potensi ekonomi daerah yang sedang berkembang di Kabupaten Karangasem yang hasil $\hat{Y}_{\text {SEKTOR }}<$ $\hat{Y}_{\text {PDRB }}$ sejumlah Rp. 500.470,73 juta serta rSEKTOR $\geq$ rPDRB sejumlah 6,02 persen adalah (1) industri pengolahan, (2) pengadaan air, pengelolaan sampah, limbah, (3) perdagangan besar dan eceran; reparasi mobil dan sepeda motor, (4) informasi 
dan komunikasi, (5) jasa keuangan dan asuransi, (6) real estate, (7) jasa perusahaan, (8) jasa pendidikan, (9) jasa kesehatan dan kegiatan sosial, (10) jasa lainnya.

Perekonomian potensial daerah yang menjadi potensi di Kabupaten Karangasem yang hasil $\hat{Y}_{\text {SEKTOR }} \geq \hat{Y}_{\text {PDRB }}$ sejumlah Rp. 500.470,73 juta serta $\mathrm{r}_{\text {SEKTOR }}<\mathrm{r}_{\mathrm{PDRB}}$ sejumlah 6,02 persen adalah (1) pertanian, kehutanan, dan perikanan, (2) konstruksi, (3) administrasi pemerintahan, pertahanan dan jaminan sosial wajib. Potensi ekonomi daerah yang tergolong terbelakang di Kabupaten Karangasem dalam periode lima tahun belakangan yang hasil $\hat{\mathrm{Y}}_{\text {SEKTOR }}<\hat{\mathrm{Y}}_{\mathrm{PDRB}}$ sejumlah Rp. 500.470,73 juta serta $\mathrm{r}_{\text {SEKTOR }}<\mathrm{r}_{\text {PDRB }}$ sejumlah 6,02 persen adalah (1) Pertambangan dan Penggalian, (2) Pengadaan Listrik dan Gas.

Kabupaten Tabanan memiliki empat sektor unggulan yaitu (1) sektor perdagangan besar dan eceran; reparasi mobil dan sepeda motor, (2) sektor penyediaan akomodasi dan makan minum, (3) sektor informasi dan komunikasi, (4) sektor administrasi pemerintahan, pertahanan dan jaminan sosial wajib. Sedangkan Kabupaten Karangasem hanya memiliki dua sektor unggulan yaitu (1) sektor transportasi dan pergudangan, (2) sektor penyediaan akomodasi dan makan minum.

Sektor berkembang pada Kabupaten Tabanan terdapat delapan sektor yaitu (1) sektor industri pengolahan, (2) sektor transportasi dan pergudangan, (3) sektor jasa keuangan dan asuransi, (4) sektor real estate, (5) sektor jasa perusahaan, (6) sektor jasa pendidikan, (7) sektor jasa kesehatan dan kegiatan sosial, (8) sektor jasa lainnya. Sedangkan Kabupaten Karangasem memiliki sepuluh sektor 
berkembang yang diantaranya merupakan (1) sektor industri pengolahan, (2) sektor pengadaan air, pengelolaan sampah, limbah, (3) sektor perdagangan besar dan eceran; reparasi mobil dan sepeda motor, (4) sektor informasi dan komunikasi, (5) sektor jasa keuangan dan asuransi, (6) sektor real estate, (7) sektor jasa perusahaan, (8) sektor jasa pendidikan, (9) sektor jasa kesehatan dan kegiatan sosial, (10) sektor jasa lainnya.

Sektor potensial yang dimiliki Kabupaten Tabanan hanya dua sektor yaitu (1) sektor pertanian, kehutanan, dan perikanan, (2) sektor konstruksi. Sedangkan Kabupaten Karangasem memiliki tiga sektor potensial diantaranya (1) sektor pertanian, kehutanan, dan perikanan, (2) sektor konstruksi, (3) sektor administrasi pemerintahan, pertahanan dan jaminan sosial wajib.

Sektor terbelakang yang dimiliki Kabupaten Tabanan bejumlah tiga sektor diantaranya (1) sektor pertambangan dan penggalian, (2) sektor pengadaan listrik dan gas, (3) sektor pengadaan air, pengelolaan sampah, dan limbah. Sedangkan Kabupaten Karangasem hanya memiliki dua sektor terbelakang diantaranya (1) sektor pertambangan dan penggalian, dan (2) sektor pengadaan listrik dan gas.

Antara Kabupaten Tabanan dengan Kabupaten Karangasem potensi ekonomi daerah yang dimiliki oleh kedua Kabupaten ini hampir sama, hanya saja sektor unggulan yang dimiliki oleh Kabupaten Tabanan lebih banyak dibandingkan dengan Kabupaten Karangasem.

Keterlibatan PAD Kabupatean Tabanan untuk menopang pendapatan daerah saat ini tergolong rendah kontribusinya. Keterlibatan Pendapatan Asli Daerah yang tergolong rendah dari jumlah penerimaan pendapatan yang artinya otonomi 
daerah pada saat penyusunan Rencana Anggaran Pendapatan dan Belanja Daerah (RAPBD) belum di dukung dengan mandirinya wilayah secara keuangan. Maka dari itu usaha meningkatkan mandirinya wilayah secara keuangan menjadi tantangan penting yang harus di hadapi Pemerintah Daerah Kabupaten Tabanan periode yang akan datang. Kemandirian keuangan daerah Kabupaten Tabanan selama kurun waktu 5 (lima) tahun (2012-2016) dapat dilihat pada Tabel 2.

Tabel 2 Tingkat Rasio Kemandirian Pemerintah Daerah Kabupaten Tabanan Tahun Anggaran 2012-2016

\begin{tabular}{ccccc} 
Tahun & PAD & Transfer + Pinjaman TPD & PAD/TPD \% & KRITERIA \\
\hline 2012 & $183.295 .006,00$ & $60.056 .604,00$ & 305,204 & Sangat Baik \\
2013 & $255.394 .018,96$ & $50.786 .178,75$ & 502,881 & Sangat Baik \\
2014 & $273.426 .482,00$ & $97.519 .624,00$ & 280,381 & Sangat Baik \\
2015 & $300.799 .020,96$ & $122.371 .327,78$ & 245,808 & Sangat Baik \\
2016 & $318.083 .799,00$ & $171.016 .876,00$ & 185,996 & Sangat Baik \\
\hline \multicolumn{5}{c}{ RATA-RATA } \\
\hline
\end{tabular}

Sumber: Data Diolah, 2017

Rasio tingkat kemandirian keuangan daerah yang tergambar pada Tabel 2, rata-rata tingkat kemandirian keuangan daerah Kabupaten Tabanan periode 20122016 sebesar 304,05 persen, oleh karena itu di klasifikasikan berdasarkan karakteristik penghitungan kemandirian keuangan wilayah dapat dilihat bahwa Kabupaten Tabanan tingkat kemandirian keuangan daerah sangat baik. Hal tersebut menunjukan Kabupaten Tabanan dalam periode 2012-2016 mempunyai kemandirian keuangan dengan baik, maka Kabupaten Tabanan dalam membiayai pengeluaran daerahnya tidak tergantung terhadap sumber dana luar atau eksternal.

PAD Kabupaten Karangasem periode 2012-2016, menunjukan penurunan pertumbuhan. Tahun 2012 pertumbuhan sejumlah 11,177 persen, diikuti dengan 
pertumbuhan pada tahun 2013 sejumlah 17,089 persen, pada tahun 2014 pertumbuhan meningkat menjadi 41, 963 persen, tahun 2015 menurun menjadi 1,545 persen, dan pada tahun 2016 pertumbuhannya sangat menurun menjadi 3,896 persen, sehingga rata-rata pertumbuhan Pendapatan Asli Daerah pada Kabupaten Karangasem periode 2012-2016 sebesar 13,57 persen. PAD Kabupatean Karangasem untuk mendukung penerimaan daerah tergolong sangat kecil kontribusinya. Perbandingan besarnya PAD dengan total penerimaan daerah periode 2012-2016 menunjukan rata-rata 16,813 persen. Peran PAD sangatlah rendah pada jumlah penerimaan pendapatan yang berarti otonomi daerah dalam menyusun Rencana Anggaran Pendapatan dan Belanja Daerah (RAPBD) belum di dukung dengan mandirinya suatu wilayah dalam keuangan. Maka dari itu upaya menaikkan mandirinya suatu wilayah dalam keuangan menjadi tantangan penting, harus di hadapi dengan Pemerintah Daerah Kabupaten Karangasem pada periode selanjutnya.

Kemandirian daerah adalah perbandingan PAD terhadap Total Penerimaan yang berasal dari Transfer Pemerintah Pusat, Provinsi dan Pinjaman (TPD) yang menjadi indikator tingkat kemandirian daerah. Kemandirian keuangan daerah Kabupaten Karangasem periode 2012-2016 terlihat pada Tabel 3 yang ditunjukan oleh rata-rata tingkat kemandirian keuangan daerah sebesar 117,41 persen, di klasifikasikan berdasarkan kriteria penilaian rasio KKD dengan tingkat kemandirian keuangan daerah sangat baik. Ini menunjukan Kabupaten Karangasem memiliki rasio KKD sangat baik, maka dari itu Kabupaten 
Karangasem dalam membiayai pengeluaran daerahnya tidak tergantung terhadap sumber dana luar atau eksternal.

Tabel 3 Tingkat Rasio Kemandirian Pemerintah Daerah Kabupaten Karangasem Tahun Anggaran 2012-2016

\begin{tabular}{ccccc}
\hline & & & & \\
Tahun & PAD & Transfer + Pinjaman TPD & PAD/TPD \% & KRITERIA \\
\hline 2012 & $144.037 .625 .901,70$ & $159.310 .120 .527,56$ & 90,413 & Sangat Baik \\
2013 & $168.652 .789 .874,71$ & $192.700 .405 .920,47$ & 87,521 & Sangat Baik \\
2014 & $239.425 .004 .469,89$ & $173.831 .152 .495,50$ & 137,734 & Sangat Baik \\
2015 & $243.125 .917 .433,60$ & $211.173 .788 .128,03$ & 115,131 & Sangat Baik \\
2016 & $233.653 .019 .710,95$ & $149.512 .946 .832,06$ & 156,276 & Sangat Baik \\
\hline \multicolumn{7}{c}{ RATA-RATA } & $\mathbf{1 1 7 , 4 1 5}$ & Sangat Baik \\
\hline \multicolumn{5}{c}{ Sumber: Data Diolah, 2017 }
\end{tabular}

Berdasarkan rasio KKD pada Tabel 2, yang ditunjukan oleh rata-rata tingkat kemandirian keuangan daerah Kabupaten Tabanan sebesar 304,05 persen, maka di klasifikasikan berdasarkan kriteria penilaian rasio $\mathrm{KKD}$ dengan tingkat kemandirian keuangan daerah sangat baik. Sedangkan rasio tingkat kemandirian keuangan daerah Kabupaten Karangasem pada Tabel 3, rata-rata tingkat kemandirian keuangan daerah Kabupaten Karangasem selama periode tahun anggaran 2012-2016 adalah 117,41 persen, sehingga di klasifikasikan menurut kriteria penilaian kemandirian keuangan daerah dapat dilihat bahwa Kabupaten Karangasem dengan tingkat kemandirian keuangan daerah sangat baik.

Dapat dilihat bahwa rata-rata besarnya tingkat kemandirian keuangan daerah Kabupaten Tabanan periode 2012-2016 sebesar 304,05 persen, lebih besar dibandingkan dengan tingkat rata-rata kemandirian keuangan daerah Kabupaten Karangasem periode 2012-2016 yang hanya 117,41 persen, ini menunjukan Kabupaten Tabanan mempunyai kemandirian keuangan sangat lebih baik dibandingkan dengan Kabupaten Karangasem, tetapi sama-sama dalam 
membiayai pengeluaran daerahnya tidak tergantung terhadap sumber dana luar atau eksternal.

Tabel 4 Uji T Rata-Rata Rasio KKD Pemerintah Daerah Kabupaten Tabanan Dengan Kabupaten Karangasem Periode 2012-2016 (t-paired)

\begin{tabular}{|c|c|c|c|c|c|c|c|c|c|}
\hline & & \multicolumn{5}{|c|}{ Paired Differences } & \multirow[b]{3}{*}{$\mathrm{t}$} & \multirow{3}{*}{\multicolumn{2}{|c|}{$\begin{array}{r}\text { Sig. (2- } \\
\text { df tailed) }\end{array}$}} \\
\hline & & \multirow[b]{2}{*}{ Mean } & \multirow{2}{*}{$\begin{array}{c}\text { Std. } \\
\text { Deviation }\end{array}$} & \multirow{2}{*}{$\begin{array}{l}\text { Std. Error } \\
\text { Mean }\end{array}$} & \multicolumn{2}{|c|}{$\begin{array}{c}95 \% \text { Confidence Interval } \\
\text { of the Difference }\end{array}$} & & & \\
\hline & & & & & Lower & Upper & & & \\
\hline $\begin{array}{l}\text { Pair } \\
1\end{array}$ & $\begin{array}{l}\text { Tabanan - } \\
\text { Karangasem }\end{array}$ & 186.639000 & 128.682901 & 52.534574 & 51.594577 & 321.683423 & 3.553 & 5 & .016 \\
\hline
\end{tabular}

Berdasarkan hasil uji $\mathrm{T}$ diketahui bahwa nilai probabilitas sebesar 0,016 > 0,05 karena nilai probabilitas sebesar 0,016 lebih besar dari 0,05, maka dapat disimpulkan bahwa terdapat perbedaan yang signifikan antara tingkat kemandirian daerah Kabupaten Tabanan dengan Kabupaten Karangasem pada data rata-rata rasio KKD Kabupaten Tabanan dengan Kabupaten Karangasem Periode 20122016 yang artinya Kabupaten Tabanan memiliki nilai rata-rata lebih tinggi dibandingkan dengan Kabupaten Karangasem.

\section{SIMPULAN DAN SARAN}

Dari hasil penelitian dan pembahasan potensi ekonomi daerah menggunakan analisis Tipologi Klassen dan pembahasan tingkat kemandirian daerah pada Kabupaten Tabanan dan Kabupaten Karangasem, maka dapat ditarik kesimulan yaitu sektor unggulan yang sama pada Kabupaten Tabanan dan Kabupaten Karangasem pada tahun 2012-2016 adalah sektor penyediaan akomodasi dan makan minum, sektor berkembang adalah industri pengolahan, sektor real estate, jasa perusahaan, jasa pendidikan, jasa kesehatan dan kegiatan sosial, jasa lainnya; 
sektor potensial adalah sektor pertanian, kehutanan, dan perikanan, sektor konstruksi; sektor terbelakang adalah sektor pertambangan dan penggalian, sektor pengadaan listrik dan gas.

Kabupaten Tabanan dan Kabupaten Karangasem periode 2012-2016 mempunyai tingkat kemandirian sangat baik, maka Kabupaten Tabanan dan Kabupaten Karangasem tidak ketergantungan oleh bantuan dari pemerintah pusat melalui dana perimbangan. Berdasarkan hasil uji $\mathrm{T}$ diketahui bahwa nilai probabilitas sebesar $0,016>0,05$, maka dapat disimpulkan bahwa terdapat perbedaan yang signifikan antara tingkat kemandirian daerah Kabupaten Tabanan dengan Kabupaten Karangasem pada data rata-rata tingkat rasio KKD Kabupaten Tabanan dengan Kabupaten Karangasem periode 2012-2016 yang artinya Kabupaten Tabanan memiliki nilai rata-rata lebih tinggi dibandingkan dengan Kabupaten Karangasem.

Saran yang dapat diberikan untuk pemerintah daerah dalam pengoptimalan potensi ekonomi daerah adalah mengutamakankan sektor yang tergolong unggulan dan potensial, tetapi tidak mengabaikan sektor lainnya seperti sektor berkembang dan sektor terbelakang. Upaya tersebut dilakukan dengan tujuan agar dapat meningkatkan peran sektor berkembang dan sektor terbelakang agar dapat bergeser menjadi sektor unggulan ataupun potensial, sehingga akhirnya seluruh sektor yang potensi ekonomi daerahnya terbelakang secara bersama-sama dapat mendukung peningkatan perekonomian daerah melalui peningkatan perolehan PDRB. 


\section{REFERENSI}

Arsyad, Lincolin. 2015. Ekonomi Pembangunan, Edisi ke 5. Yogyakarta: UPP STIM YKPN.

Arsyad, Licolin. 1999. Pengantar Perencanaan dan Pembangunan Ekonomi Daerah,Edisi pertama. Yogyakarta: Penerbit BPFE.

Ascani, Andrea., Riccardo, Crescenzi., Simona, Iammarino. 2012. Regional Economic Development: A Review. The Research Leading To These Resulth Has Recaived Funding From The European Community's 2(5):2-26.

Afandiyev, Vusat., Zakir, Eminov., Saleh, Nagiyev. 2014. Economic And Geographic Factors Affecting The Defelopment Of Greater Baku. Journal of Urban and Regional Analysis: 6 (2) : 203-218.

Andriyani, Sri. 2014. Analisis Pusat Pertumbuhan di Kabupaten Karangasem. Skripsi Fakultas Ekonomi dan Bisnis Universitas Udayana, Denpasar.

Ayu, Luh Nyoman Fajar Nur. 2016. Analisis Potensi Ekonomi Daerah Provinsi Bali. Skripsi Fakultas Ekonomi dan Bisnis Universitas Udayana, Denpasar.

Baliterkini.wordpress.com/2009/09/05/kabupaten-bangli.

Boronenko, Vera., and Zane, Zeibote. 2011. The Potential Of Cluster Development And The Role Of Cluster Support Policies In Latvia. Economic Annals 56 (191) : 35-67.

Badan Pusat Statistik (BPS). 2017. Produk Domestik Regional Bruto Kabupaten Karangasem Menurut Lapangan Usaha 2011-2015. BPS Kabupaten Karangasem.

Badan Pusat Statistik (BPS). 2017. Produk Domestik Regional Bruto Kabupaten Tabanan Menurut Lapangan Usaha 2011-2015. BPS Kabupaten Tabanan.

Dominica, Rubidiyanti. 2010. Analisis Sektor Perekonomian di Kabupaten Bogor. Tesis Fakultas Ekonomi Program Studi Megister Perencanaan dan Kebijakan Publik, Jakarta.

Emila. 2006. Modul Ekonomi Regional. Diktat Kuliah pada Jurusan Ilmu Ekonomi Fakultas Ekonomi Universitas Jambi.

Erawati., dan Mahendra, Yasa. 2012. Analisis Pola Pertumbuhan Ekonomi dan Sektor Potensial Kabupaten Klungkung. E-Jurnal Ekonomi Pembangunan Universitas Udayana, 1 (1) : 41-61. 
Feriyanto, Nur. 2016. Imbalanced Relationship Betewwen Regional Economic Growth And Income Percapita: An Empirical Analysis In Yogyakarta Special Province. I J A B E R: 14 (10) : 6739-6754.

Fattah, Sanusi., and Abdul, Rahman. 2013. Analysis of Regional Economic Development in the Regency/Municipality at South Sulawesi Province In Indonesia. Journal of Economics and Sustainable Development: 4(1) : $1-9$.

Fitriyanti, Ismi Rizki. 2009, "Pengaruh Pendapatan Asli Daerah dan Belanja Pembangunan Terhadap Kemandirian Daerah dan Pertumbuhan Ekonomi (Studi pada Kota, Kabupaten dan Provinsi DIY)" Skripsi,Yogyakarta: Fakultas Ekonomi UMY. TidakTerpublikasi

Halim, Abdul. 2002. Akuntansi Keuangan Daerah- Akuntansi Sektor Publik, Edisi Ketiga, Salemba Empat, Jakarta.

Hafidh, Aula Ahmad. 2013. Analisis Rasio Keuangan Daerah Dalam Mempengaruhi Belanja Modal Publik Bagi Pertumbuhan Ekonomi.Jurnal Penelitian Humaniora: 18(2) :109-120.

Husna, Nailatul., Irwan, Noor., Machammad, Rozikin. 2012. Analisis pengembangan potensi ekonomi lokal untuk menguatkan daya saing daerah di Kabupaten Gresik. Jurnal Administrasi Publik, FIA Universitas Brawijaya Malang: 1(1) : 188-196.

Herath, Janaranjana., Tesfa, G. Gebremedhin., Blessing, M. Maumbe. 2012. A Dynamic Shift Share Analysis of Economic Growth in West Virginia. Graduate Research AssistantResearch Paper: 3(6) : 1-23.

Huggins, Robert., Hiro, Izushi., Piers, Thompson. 2013. Regional Competitiveness: Theories and Methodologiesfor Empirical Analysis. The Business and Economics Research Journal: 6(2) : 156-172.

Kerimoglu, Ebru., and B. Can, Karahasan. 2012. Geography Of Talent For Understanding Regional Disparities In Spain. Jurnal Urban dan Regional Analisis: 6(2) :103-128.

Kristiano, Natal. 2015. Modul Otonomi Daerah. Diktat Kuliah pada Jurusan Politik dan Kewarganegaraan Fakultas Ilmu Sosial Universitas Negeri Semarang.

Mahmudi. 2009. Manajemen Keuangan Daerah. Jakarta: Erlangga.

Munandar, Tb. Ai., and Edi, Winarko. 2015.Regional Development Classification Model using Decision Tree Approach.International Journal of Computer Applications: 114(8) : 28-33. 
Nuryanti. 2015. Pengaruh Pendapatan Asli Daerah dan Dana Bagi Hasil terhadap Pertumbuhan Ekonomi melalui Belanja Langsung di Kabupaten/Kota Provinsi Bali. Skripsi Fakultas Ekonomi dan Bisnis Universitas Udayana, Denpasar.

Nurfatimah, Annisa. 2013. Analisis Potensi Pertumbuhan Ekonomi Kabupaten/Kota di Provinsi Bali. Skripsi Sarjana Jurusan Ilmu Ekonomi dan Bisnis Fakultas Ekonomi dan Bisnis Universitas Islam Negeri Syarif Hidayatullah, Jakarta.

Paul, Suman. 2014. Finances And Governance Of Urban Local Bodies: An Approach Of Urban Development Perspective From A Developing Country (India). Journal of Urban and Regional Analysis: 6(2) : 181201.

Saggaf, M. Said. 2013. Strategy of Regional Development Policy Based on Potential Local toward Shifting Economic Structure of Bantaeng Regency. EnvironmentalManagement and Sustainable Development: 2(2) : 137-152.

Saragih, Juli Panglima. 2003. Desentralisasi Fiskal dan Keuangan Daerah Dalam Otonomi, Ghalia Indonesia: Jakarta.

Soemantri. 2014. Otonomi Daerah. Bandung: PT Remaja Rosdakarya.

Sinurat, Marja. 2016. CianjurRegency Regional Economy Potential Analysis. Jurnal Internasional Ilmu Sosial: 45(1) : 1-13.

Sinaga, Dearlina. 2015. Determination Analysis of Leading Economic Sector Against Forming Region GDP in Simalungun. International journal of Innovative Research in Management: 3(4) : 1-12.

Suparmoko, M. 2002. Ekonomi Publik untuk Keuangan dan PembangunanDaerah. Yogyakarta: Andi Offset.

Tahar, Afrizal., dan Maulida, Zakhiya. 2011. Pengaruh Pendapatan Asli Daerah Dan Dana Alokasi Umum Terhadap Kemandirian Daerah Dan Pertumbuhan Ekonomi Daerah .Jurnal Akuntansi dan Investasi: 12(1) : 88-99.

Tjahjono, Achmad., dan Rika, Oktavianti. 2016. Pengaruh Rasio Evektivitas Pendapatan Asli Daerah, Dana Alokasi Umum Dan Dana Alokasi Khusus Terhadap Tingkat Kemandirian Keuangan Daerah Di Provinsi DIY .Jurnal Kajian Bisnisi: 24(1) : 25-34.

Tulla, Antoni Francesc., Ana, Vera., Anna, Badia., Carles, Guirado., Natalia, Valldeperas. 2014. Rular And Regional Development Policies In Europe: Social Farming In The Common Strategic Framework. Jurnal Urban dan Regional Analisis: 6(1) : 35-52. 
Undang-Undang No. 5 Tahun 1974 Tentang Pokok-Pokok Pemerintahan di Daerah.

Undang-Undang No. 22 Tahun 2004 Tentang Pemerintahan Daerah.

Undang-Undang No. 25 Tahun 2004 Tentang Sistem Perencanaan Pembangunan Nasional.

Undang-Undang No. 32 Tahun 2004 Tentang Pemerintah Daerah.

Undang-Undang No. 33 Tahun 2004 Tentang Perimbangan Keuangan Daerah Pemerintah Pusat dan Pemerintah Daerah.

Undang-Undang No. 34 Tahun 2000 Tentang Pajak Daerah dan Retribusi Daerah.

Putro, Nugroho S. 2010. Pengaruh Pertumbuhan Ekonomi, Pendapatan Asli Daerah dan Dana Alokasi Umum terhadap Pengalokasian Anggaran Belanja Modal (Studi Kasus Pada Kabupaten/Kota di Provinsi Jawa Tengah).Skripsi Fakultas Ekonomi Universitas Diponogoro.

Puspitawati, Linda Tustiana. 2013. Analisis Perbandingan Faktor-Faktor Penyebab Ketimpangan Pembangunan Antar Kabupaten/Kota di Kawasan Kedungsapur. Economics Development Analysis Journal Universitas Negeri Semarang, 2 (2) : 1-16.

Yusuf, Maulana. 1999. Model Rasio Pertumbuhan (MRP) sebagai Salah Satu Alat Analisis Alternatif dalam Perencanaan Wilayah dan Kota, Aplikasi model: Wilayah Bangka-Belitung. Jurnal Ekonomi dan Keuangan Indonesia, 48(2) : 105-233. 